\title{
Yetmiş Beş Yaş ve Üstü Hastalarda Kemik İliği Değerlendirmesinin Klinik Yaklaşıma Katkısı Var mıdır?
}

\author{
Pelin AYTAN ${ }^{1}$, Mahmut YERAL ${ }^{1}$, Emrah Nazım KOÇER ${ }^{2}$, Can BOĞA $^{1}$ \\ 1 Adana Başkent Üniversitesi Tıp Fakültesi, İç Hastalıkları Anabilim Dalı, Hematoloji Bilim Dalı, Adana. \\ 2 Adana Başkent Üniversitesi Tıp Fakültesi, Patoloji Anabilim Dalı, Adana.
}

\begin{abstract}
ÖZET
Yaşlı hastalarda, özellikle de orta/ileri yaşlılık olarak tanımlanan $\geq 75$ yaş grubunda kemik iliği değerlendirmenin klinik uygulamalardaki yeri net değildir. Bu çalışmada $\geq 75$ yaşındaki hastalarda yapılan kemik iliği biyopsi ve aspirasyon endikasyonlarının, sonuçlarının ve yapılan kemik iliği incelemesinin klinik yaklaşıma ve sonuçlara katkısının değerlendirilmesi amaçlanmıştır. Ocak 2014- Aralık 2018 yılları arasında kliniğimizde kemik iliği incelemesi yapılan tüm $\geq 75$ yaş hastalar retrospektif olarak değerlendirildi. Hastaların klinik özellikleri ve laboratuvar kan değerleri, periferik yayma, kemik iliği aspirasyon ve biyopsi sonuçları, aldıkları tedaviler ve sağ kalımları değerlendirildi. Çalışmaya dâhil edilen 81 hastanın ortalama yaşı 80,4 \pm 4 yıldı (75-95). İșleme bağlı komplikasyon görülmedi. Sitopeniler en sık endikasyondu. Anemi \%87,6 oranında görülürken, lökopeni $\% 25,9$ ve trombositopeni \%50,6 oranında görülmekteydi. En sık konulan tanı miyelodisplastik sendromdu (MDS). Yine multipl miyelom, miyeloproliferatif hastalıklar ve non-Hodgkin lenfoma MDS'yi takip ediyordu. Aspirasyon ve biyopsi yüksek oranda uyum göstermekteydiler. Genel olarak tedavi alan hastalarda ortanca sağ kalım süresi 69 ayken, almayan grupta 35 aydı. Yine 2 yıllık genel sağ kalım tedavi alan hastalarda $\% 57$ iken, almayan hastalarda $\% 41,7$ idi. Sonuç olarak $\geq 75$ yaş hastalarda, ileri yaşa özgü hematolojik ve bazı non-hematolojik hastalıkların tanısının konulması için kemik iliği incelemesi güvenle yapılabilir. Kemik iliği incelemesinin endikasyonları çocuk ve genç erişkinlerinkinden farklıdır. Bu incelemeyle tanısı konulan hastalıklarda uygulanan tedaviler ile sağ kalım artmaktadır. Bu nedenle endikasyon varlığında, tanının konulması ve uygun tedavinin başlanması yolu ile sağ kalımı artırmak için kemik iliği incelemesi bu yaş grubuna önerilmelidir.
\end{abstract}

Anahtar Kelimeler: Kemik iliği. Biyopsi. Aspirasyon. Yetmiş beş yaş üstï. Yaşlı.

Does Bone Marrow Evaluation Have a Contribution to Clinical Management in Patients Seventy Five Years and Older?

\begin{abstract}
In clinical practice the role of bone marrow evaluation (BM) in the elderly, especially in patients over 75 years old who are referred as middle/advanced old, is not clear. In this study the aim was to assess the indications, results and the contribution of BM aspiration and biopsies to the clinical management and outcomes in patients over 75 years old. All $\geq 75$ years old patients to whom BM evaluation was performed between January 2014 and December 2018 in our clinic were assessed retrospectively. The clinical properties, laboratory, peripheral blood smear and BM aspiration/biopsy results, the applied treatments and the survival outcomes were evaluated. The mean age of the 81 included patients was 80.4 \pm 4 (75-95). There was no procedure-related complication. Cytopenias were the most frequent indication. Anemia, leukopenia and thrombocytopenia were detected in 87.6\%, 25.9\% and 50.6\% respectively. Myelodyspastic syndrome (MDS) was the most frequent diagnosis. Multiple myeloma, myeloproliferative diseases and non-Hodgkin lymphoma were the following diagnoses. Aspiration and biopsy showed high correlation. In general the median survival was 69 months in the treated patients and 35 months in non-treated patients. Twoyears overall survival was $57 \%$ in the treated and $41.7 \%$ in non-treated patients. In conclusion in order to diagnose hematological and some non-hematological disorders confined to advanced age, BM evaluation may be performed safely in patients over 75 years old. The indications of BM evaluation is different than childhood and younger adulthood. Treatment of disorders that were diagnosed with this procedure provides a survival benefit. For this reason whenever indicated, in order to diagnose and improve the survival with appropriate treatment, BM evaluation may be offered to patients in this age group.
\end{abstract}

Key Words: Bone marrow. Biopsy. Aspiration. Over seventy five years old. Elderly.

Geliş Tarihi: 12.Mayıs.2020 Kabul Tarihi: 14.Ağustos.2020
Dr. Pelin AYTAN

Adana Başkent Üniversitesi Tıp Fakültesi,

İç Hastalıkları Anabilim Dalı,

Hematoloji Bilim Dalı,

Dadaloğlu Mah, 2591 Sk, 4/A

Yüreğir / Adana

Tel: 05327803572

E-posta: drpelinaytan@gmail.com
Yazarların ORCID ID Bilgisi:

Pelin AYTAN: 0000-0002-4213-1565

Mahmut YERAL: 0000-0002-9580-628X

Emrah Nazım KOÇER: 0000-0003-3636-

8109

Can BOĞA: 0000-0002-9680-1958 
Tüm dünyada olduğu gibi ülkemizde de ortalama insan ömrü uzamaktadır. Türkiye'de beklenen ortalama yaşam süresi 78,3 yll $^{1}$ iken yaşlı nüfusun tüm nüfus içindeki oranı da gittikçe artmaktadır. Geriatrik yaş grubu olarak kabul edilen altmış beş yaş üstü nüfus ülkemizin toplam nüfusunun $\% 9,1$ 'ini oluştururken, toplumun \%3,38'i yetmiş beş yaş ve üzerinde$\operatorname{dir}^{1}$. Altmışbeş yaşından sonra beklenen yaşam süresi kadınlarda 19,4 yıl iken, erkeklerde 16,2 yıldır (ortalama 17,9 yıl). Artan yaşlı nüfus ile birlikte aralarında hematolojik hastalıkların da olduğu yaşlılıkta daha sık görülen hastalıkların görülme sıklığının artacağı aşikârdır.

Kemik iliğinin değerlendirilmesi tüm yaş gruplarında hematolojik ve birçok non-hematolojik hastalıkların tanısının konulmasında ve takibinde anahtar rol oynar. Yaş ile birlikte kemik iliğinin kompozisyonu değişmektedir. Genel olarak hematopoietik doku azalırken yağ dokusu $\operatorname{artar}^{2}$. Çocuk ve erişkinlerde kemik iliği örneklemesinin endikasyonları ve klinik yararı net olarak ortaya konulmuş iken ${ }^{3,4}$, yaşlı hastalarda, özellikle de orta/ileri yaşlılık olarak tanımlanan $\geq 75$ yaş grubunda $^{5}$ az sayıda klinik çalışma nedeniyle net değildir. $\mathrm{Bu}$ bilgi ülkemizde de yaşlı nüfusun gittikçe artıyor olması nedeniyle önemlidir.

Aspirasyon ve biyopsi kemik iliği değerlendirmesi için kullanılan iki önemli tekniktir. Birbirinin tamamlayıcısı olan bu iki teknikte aspirasyon ile hücresel morfolojik değerlendirme yapılırken, biyopsi de selüleritenin, fibrozisin ve infiltratif hastalıkların değerlendirilmesine olanak sağlar ${ }^{6}$. Bu çalışmada 75 yaş ve üzeri orta/ileri yaşlı hastalarda yapılan kemik iliği biyopsi ve aspirasyon endikasyonlarının, sonuçlarının ve yapılan kemik iliği incelemesinin klinik yaklaşıma ve sonuçlara katkısının değerlendirilmesi amaçlanımıştir.

\section{Gereç ve Yöntem}

Kliniğimizde Ocak 2014- Aralık 2018 yılları arasında çeşitli nedenlerden dolayı kemik iliği aspirasyon ve biyopsi yapılan tüm yetmiş beş yaş ve üzeri hastalar retrospektif olarak değerlendirildi. Hastaların demografik özellikleri, başvuru şikâyetleri, komorbid hastalık durumları, kemik iliği biyopsi anında laboratuvar kan değerleri, periferik yayma sonuçları, kemik iliği aspirasyon ve biyopsi rapor sonuçları, aldıkları tedaviler ve sağ kalımları kaydedildi. Merkezimizde standart olarak tüm kemik iliği aspirasyon ve biyopsiler posterior superior iliak kemik çıkıntısından aynı biyopsi iğnesi girilip kemiğin farklı bölgesinden iki ayrı örnekleme yapılarak alınmaktadır. Aspirasyon ve impirint yayması için giemsa boyası, biyopsi kesitleri için hematoksilen/eosin boyası kullanılmaktadır. PAS, MPO, retikülin boyaları ise gerekli olduğu durumlarda kullanılmaktadır. Kemik iliği biyopsi sonuçları altın standart olarak kabul edilmekte ve tanı bu sonuçlara dayalı olarak konulmaktadır. Kemik iliği aspirasyon ve biyopsi endikasyonları sitopeniler (en az bir adet), önceden tanı almış lenfomanın takibi, daha önce tanı almış miyelodisplastik sendromun (MDS) takibi, lökositoz ve trombositozdur. Tüm verilere hasta dosyaları ve hastane elektronik veri tabanı üzerinden ulaşıldı. Verilerine ulaşılamayan, takiplerine gelmeyen, endikasyonu tam olmayan ve hem aspirasyon hem de biyopsi sonucu birlikte olmayan hastalar çalışma d1şında bırakıldı. Çalışma için üniversitenin etik kurulundan onay alınd1 (KA20/48).

Kliniğimizde tanı konulan hastalıklar güncel kılavuzlara göre tedavi edilmektedir. Genel olarak MDS tedavisi için hipometile edici ajanlardan azasitidin ve eritropoietin stimüle edici ajanlar, akut miyeloid lösemi (AML) tedavisinde azasitidin, miyeloproliferatif hastalık (MPH) ve miyelofibroz tedavilerinde hidroksiüre, anagrelid ve JAK inhibitörü ruksolitinib, multipl miyelom (MM) tedavisinde immünmodülatörler, proteazom inhibitörleri, melfalan ve non-Hodgkin Lenfoma (NHL) tedavisinde R-CHOP (Rituksimab, siklofosfamid, doksorubisin, vinkristin, prednol), R-FC (Rituksimab, fludarabin, siklofosfamid), aplastik anemi tedavisinde siklosporin kullanılmıştır.

\section{Istatistiksel Analiz}

Analizler SPSS programı kullanılarak yapıldı. Veriler yüzde, ortalama \pm standart sapma veya ortanca (minimum-maksimum) olarak sunuldu. Sağ kalım analizi Kaplan Meier analizi yapılarak gerçekleştirildi. Sağ kalımlar ortanca \pm standart hata olarak gösterildi. Sağ kalım \%50'nin altına düşmediği durumlarda ortanca değerine erişilemeyeceğinden bu durumda sağ kalım ortalama \pm standart sapma ile gösterildi. Tedavi alan ve almayan grupların sağ kalım açısından karşılaştırılması için log rank testi kullanıldı. Anlamlılık seviyesi olarak p değeri $<0,05$ olarak alındı.

\section{Bulgular}

Dört yıllık zaman diliminde $\geq 75$ yaşında olan toplam 85 hastaya kemik iliği değerlendirmesi yapılmıştı. Bu hastalardan 4 tanesi takiplerine gelmedikleri için çalışma dışı bırakıldı. Çalışmaya dahil edilen 81 hastanın ortalama yaşı $80,4 \pm 4$, yaş aralığı $75-95$ yıl idi. Hastaların \%42'si kadın, \%58'i erkeklerden oluşuyordu ve kadın/erkek oranı 0,72 idi. Tüm hastalara kemik iliği aspirasyonu ve trefin biyopsisi eşzamanlı uygulanmış olup, periferik kan yaymaları ve impirint yaymaları birlikte incelenmişti. Hastalar en sık halsizlik $(\% 55,6)$, ikinci sıklıkta bel ağrısı $(\% 13,6)$ ve karın ağrıs1- kilo kaybı $(\% 13,6)$ şikâyetleri ile başvurmuşlardı. En sık eşlik eden komorbid durum hipertansi- 


\section{Yaşlılarda Kemik İliği Değerlendirmesi}

yon $(\% 18,5)$ olup onu konjestif kalp yetmezliği $(\% 17,3)$ ve diyabetes mellitüs $(\% 14,8)$ takip etmekte idi. Tüm hastaların laboratuvar değerleri Tablo I'de gösterilmiştir. Anemi kadınların \%79,4'ünde (n: 27/34), erkeklerin ise \%93,6'sında (n: 44/47) görülen en sik saptanan bulguydu. Trombositoz $(>400.000$ $\left./ \mathrm{mm}^{3}\right) \% 7,4$ (n: 6/81) oranında görülürken, trombositopeni $\left(<130.000 / \mathrm{mm}^{3}\right) \% 50,6$ (n: $\left.41 / 81\right)$ oranında görüldü. Tüm hastalarda hem lökopeni $\left(<4500 / \mathrm{mm}^{3}\right)$ hem de lökositoz (>11.500/mm3) \%25,9 oranında görüldü. Folik asit eksikliği tüm hastaların \%8,6'sında (kadınlarda \%7,7, erkeklerde \%9,1) mevcut idi. Yine vitamin B12 ve demir eksiklikleri tüm hastalarda sirasıyla \%7,1 (kadinlarda \%3,7, erkeklerde \%9,3) ve $\% 49,1$ oraninda (kadinlarda \%56, de \%43,8) görülmekte idi.

Tablo I. Hastaların laboratuvar değerleri

\begin{tabular}{ll}
\hline \multicolumn{2}{c}{ Ortalama \pm SS / Ortanca (min-maks)* } \\
Hemoglobin (g/dL) & $9,2 \pm 2,3$ \\
Hematokrit (\%) & $28,1 \pm 7,3$ \\
Beyaz küre $\left(/ \mathrm{mm}^{3}\right)$ & $6585(690-126.000)$ \\
MCV & $89,6 \pm 12,6$ \\
Kreatinin (mg/dL) & $1,1(0,4-5,5)$ \\
Sedimentasyon (mm/saat) & $41(3-140)$ \\
RDW (\%) & $18,2 \pm 3,4$ \\
Trombosit $\left(/ \mathrm{mm}^{3}\right)$ & $134.000(4000-1.000 .000)$ \\
Vitamin B12 $(\mathrm{pg} / \mathrm{mL})$ & $414(106-2000)$ \\
Demir (mcg/dL) & $58(5-218)$ \\
Ferritin (ng/mL) & $219(24-1650)$ \\
Folat (ng/mL) & $7,5(1,5-24)$ \\
LDH (U/L) & $224(100-1114)$ \\
TSH (mlU/L) & $1,4(0,14-11,8)$ \\
\hline
\end{tabular}

MCV: Ortalama korpüsküler hacim, RDW: Kırmızı hücre dağılım genişliği, LDH: Laktik dehidrogenaz, TSH: Tiroid stimülan hormon

*: Veriler dağılımlarına göre ortalama \pm standart sapma veya ortanca (minimum - maksimum) olarak gösterilmiştir.
Periferik yayma incelemesinde tespit edilen bulgular Tablo II'de, kemik iliği aspirasyon ve biyopsi sonuçlar1 ile her iki yöntemin uyum durumu Tablo III'te gösterilmiştir. Hastaların \%12,3'ünde kemik iliği biyopsi sonuçları normal olarak bulunurken, en sik olarak saptanan hastalıklar sırasıyla MDS ile MM idi. Bu hastalıkları MPH ve NHL izlemekte idi (Tablo III). Aspirasyon incelemesi sonucunda hastaların \%14,8'inde normal bulgular rapor edilmiş iken, biyopsi ile olan uyum \%70 olarak bulundu. Biyopsi yapılmamış olsa idi sadece aspirasyon ile iki MDS, bir miyelofibroz, bir MM, bir önemi belirsiz monoklonal gamopati (MGUS) vakası atlanacak idi. Her iki yöntem hematolojik malignansilerden KLL, AML ve NHL tanıları için yüzde yüz uyumlu iken, genel olarak MM (\%88,9), MPH $(\% 87,5)$ ve MDS $(\% 77,8)$ tanılarında yüksek oranda uyum göstermekteydiler.

Table II. Periferik yayma bulguları

\begin{tabular}{lll}
\hline & Sayı & Yüzde \\
Normal & 14 & 17,3 \\
Polikromazi + trombositopeni + anizositoz & 12 & 14,8 \\
MDS ile uyumlu & 11 & 13,6 \\
Miyeloproliferatif hst & 8 & 9,9 \\
Polikromazi + anizositoz + makrositoz & 10 & 12,3 \\
AML & 4 & 4,9 \\
Lenfoplazmositer hücre & 2 & 2,5 \\
Demir eksikliği anemisi ile uyumlu & 5 & 6,2 \\
KLL ile uyumlu & 3 & 3,7 \\
Nötrofilik lökositoz & 3 & 3,7 \\
Rulo formasyonu & 6 & 7,4 \\
Toksik granülasyon & 1 & 1,2 \\
Talasemi taşııcılığı ile uyumlu & 1 & 1,2 \\
Lenfomonositoz & 1 & 1,2 \\
\hline
\end{tabular}

MDS: Miyelodisplastik Sendrom, AML: Akut myeloid lösemi, KLL: Kronik lenfosittik lösemi

Tablo III. Kemik iliği biyopsi ve aspirasyon sonuçları ve her iki yöntemin korelasyonu

\begin{tabular}{|c|c|c|c|c|c|c|c|c|c|c|c|c|c|}
\hline & \multicolumn{13}{|c|}{ ASPIRASYON } \\
\hline & Normal & $\begin{array}{l}\text { Eritroid MDS } \\
\text { Hiperplazi }\end{array}$ & $\mathrm{MPH}$ & AML & MM & \multirow[t]{2}{*}{ LPS } & \multicolumn{2}{|c|}{$\begin{array}{l}\text { Hiperselüler } \\
\text { hücre }\end{array}$} & \multirow[t]{2}{*}{$\mathrm{KLL}$} & \multirow[t]{2}{*}{$\mathrm{NHL}$} & \multicolumn{2}{|c|}{ Hiposellüler } & \multirow[t]{2}{*}{ Toplam(\%) } \\
\hline & & & & & & & & & & & & & \\
\hline Normal & 7 & & & & & & & 3 & & & & & $10(12,3)$ \\
\hline MDS & 2 & 1 & 21 & & & & & 2 & & & & 1 & $27(33,3)$ \\
\hline Miyelofibrozis & 1 & & & 2 & & & & & & & & & $3(3,7)$ \\
\hline MPH & & & & 7 & & & & 1 & & & & & $8(9,9)$ \\
\hline AML & & & & & 4 & & & & & & & & $4(4,9)$ \\
\hline MM & 1 & & & & & 8 & & & & & & & $9(11,1)$ \\
\hline NonDX & & & & & & 1 & 1 & 1 & & & & & $3(3,7)$ \\
\hline $\mathrm{KLL}$ & & & & & & & & & & 5 & & & $5(6,2)$ \\
\hline $\mathrm{NHL}$ & & & & & & & & & & & 8 & & $8(9,9)$ \\
\hline $\mathrm{AA}$ & & & & & & & & & & & 2 & & $2(2,5)$ \\
\hline MGUS & 1 & & & & & & & & & & & & $1(1,2)$ \\
\hline KH Anemisi & & & & & & & 1 & & & & & & $1(1,2)$ \\
\hline $\begin{array}{l}\text { TOPLAM } \\
(\%)\end{array}$ & $\begin{array}{l}12 \\
(14,9)\end{array}$ & $\begin{array}{l}1 \\
(1,2)\end{array}$ & $\begin{array}{l}21 \\
(25,9)\end{array}$ & $\begin{array}{l}9 \\
(11,1)\end{array}$ & $\begin{array}{l}4 \\
(4,9)\end{array}$ & $\begin{array}{l}9 \\
(11,1)\end{array}$ & $\begin{array}{l}1 \\
(1,2)\end{array}$ & $\begin{array}{l}8 \\
(9,9)\end{array}$ & & $\begin{array}{l}5 \\
(6,2)\end{array}$ & $\begin{array}{l}8 \\
(9,9)\end{array}$ & $\begin{array}{l}3 \\
(3,7)\end{array}$ & 81 \\
\hline
\end{tabular}

MDS: Miyelodisplastik Sendrom, MPH: Miyeloproliferatif hastalık, AML: Akut myeloid lösemi, MM: Multipl myelom, NonDX: Non-diagnostik, KLL: Kronik lenfositik lösemi, NHL: Nonhodgkin lenfoma, AA: Aplastik anemi, MGUS: Önemi belirsiz monoklonal gamopati, KH Kronik hastalık, LPS Lenfoplazmositer Lenfoma 
Biyopsilerinin \%9,9'unda retikülin lif derecesi 3, \%21'inde derece 2 ve \%38,3'ünde derece 1 saptanıp \%22,2'sinde retikülin lif saptanmamıştı. Altı hastanın retikülin lif derecesi değerlendirilmemişti.

Tüm hastalarda kemik iliği değerlendirmesini takiben toplam ortanca sağ kalım süresi 29 (1-81) ay olarak bulundu. Hastaların \%59,3'ü (n:48) hayatta iken, \%40,7'si (n:33) hayatta değildi. Hayatını kaybeden 33 hastanın 13'ü $(\% 39,4)$ kemik iliği aspirasyon/biyopsi yapıldıktan sonra 6 ay içinde hayatını kaybetmişti.

Biyopsilerinde anlamlı patolojik bulgu saptanmayan 10 hasta dışındaki hastaların tespit edilen hastalıklarına yönelik tedavi alıp almadıklarına göre sağ kalım karşılaştırmaları Şekil 1'de gösterilmiştir. Kırk dokuz hastaya (\%69) tedavi verilmiş ve bu hastaların 29 tanesi $(\% 59,2)$ hayatta kalmıştır. Bu hastaların sağ kalım ortanca ( \pm standart hata) süresi $69 \pm 21,6$ ay (\%95 GA: 26,7-111,3) olarak bulunmuștur. Tedavi almayan 22 hastanın 11 tanesi (\%50) hayatta kalmış ve ortanca sağ kalım süreleri $35 \pm 12,8$ ay (\%95 GA: 9,9-60) olarak bulunmuştur ve her iki grupta sağ kalım açısından istatistiksel olarak anlamlı bir fark tespit edilmemiştir (Log rank $\chi^{2}$ : 0,92, $\left.\mathrm{p}=0,338\right)$ (Şekil 1). Tedavi alan ve almayan hastaların 2 ve 5 yıllık sağ kalım oranları sirasiyla $\% 67,1$ ile $\% 57$ ve $\% 58,4$ ile \%41,7 idi (Şekil 1).

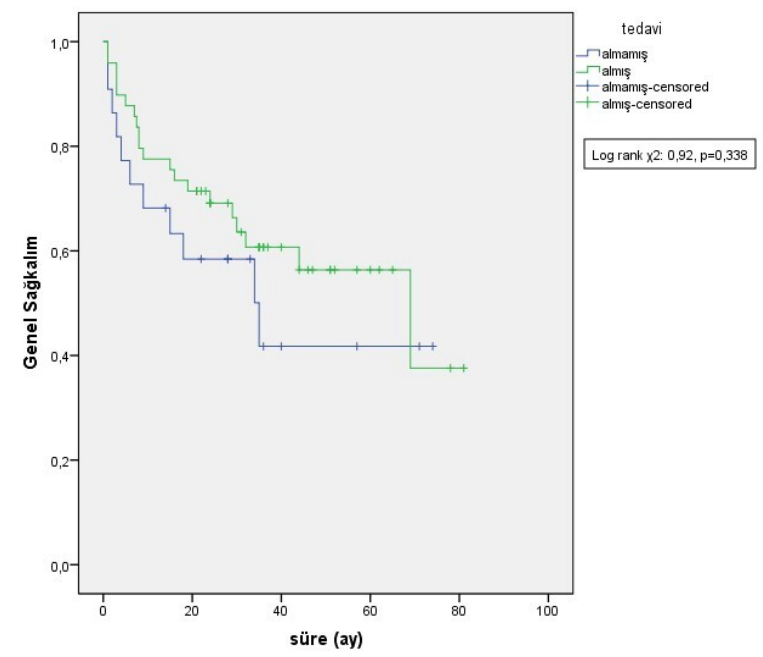

Şekil 1.

Biyopsi sonucunda hematolojik hastalık tanısı alan hastaların tedavi alıp almamaya göre să̆ kalımlarının karşılaştırılması

Tedavi vermenin hangi yaş grubu hastalarda daha etkili olduğunu belirlemek için hastalar 75-79, 80-84 ve $\geq 85$ yaş olmak üzere 3 gruba ayrıldı. Bu yaş gruplarında tedavi alan ve almayan hastaların sağ kalımları Şekil 2-4'te gösterilmiştir. $\geq 85$ yaş hastalarda tedavi almayan grupta ortanca sağ kalım $4 \pm 7,9$ ay (\%95 GA 0-19,6), alan grupta $30 \pm 8,8$ ay (\%95 GA 12,7-47,3) idi (Log rank $\left.\chi^{2}: 0,96, p=0,328\right)$ (Şekil 2). İki yıllık sağ kalım tedavi almayan grupta \%33,2 iken, tedavi alan grupta \%62,5 olarak bulundu. 80-84 yaş aras1 tedavi almayan hastalarda ortanca sağ kalım $34 \pm 24,5$ ay (\%95 GA $0-81,9)$ ve 2 y1llı sağ kalım \%58 iken, tedavi alanlarda sağ kalım $69 \pm 18,4$ ay $(32,9-105,0)$ ve 2 yıllık sağ kalım \%65 idi (Log rank $\chi^{2}$ : 0,94, $\mathrm{p}=0,331$ ) (Şekil 3). 75-79 yaş grubundaki hastalarda sağ kalım ortanca değerlerine ulaşılamadı. Ortalama sağ kalım değerleri ise tedavi almayan grupta 49,6 \pm $9,7$ ay (\%95 GA $30,6-68,6)$ ve 2 y1llı sağ $11 \mathrm{~m} \% 62,3$ iken, tedavi alan grupta sağ kalım ortalamas1 $57,9 \pm 7,8$ ay (\%95 GA 42,7-73,1) ve 2 y1llık sağ kalım \% 72,2 idi (Log rank $\left.\chi^{2}: 0,11, p=0,74\right)$ (Şekil 4).

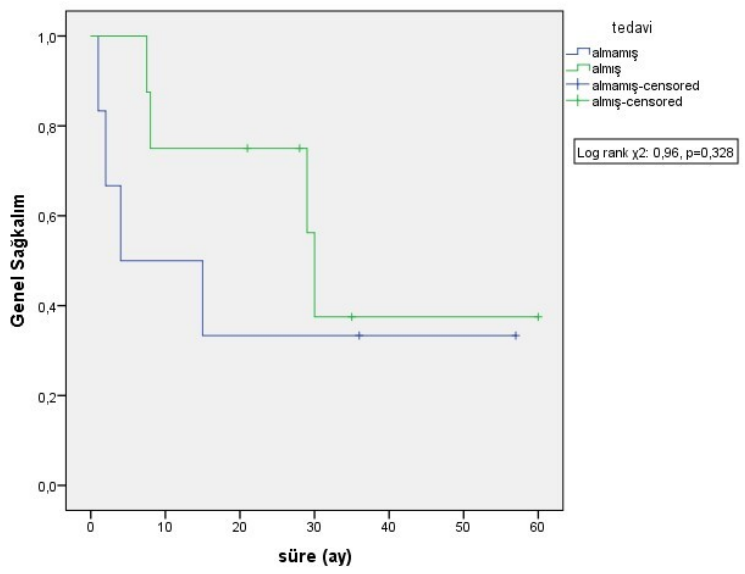

Şekil 2.

Seksen beş yaş ve üzeri hastalarda tedavi alanlarla almayanların sağ kalım karşılaştırması

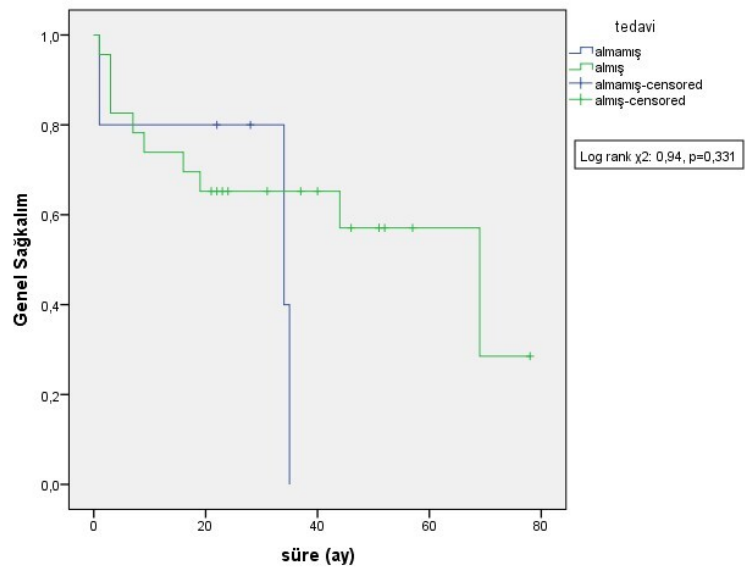

Sekil 3.

Seksen - seksen dört yaş hastalarda tedavi alanlarla almayanların săg kalım karşılaştırması 


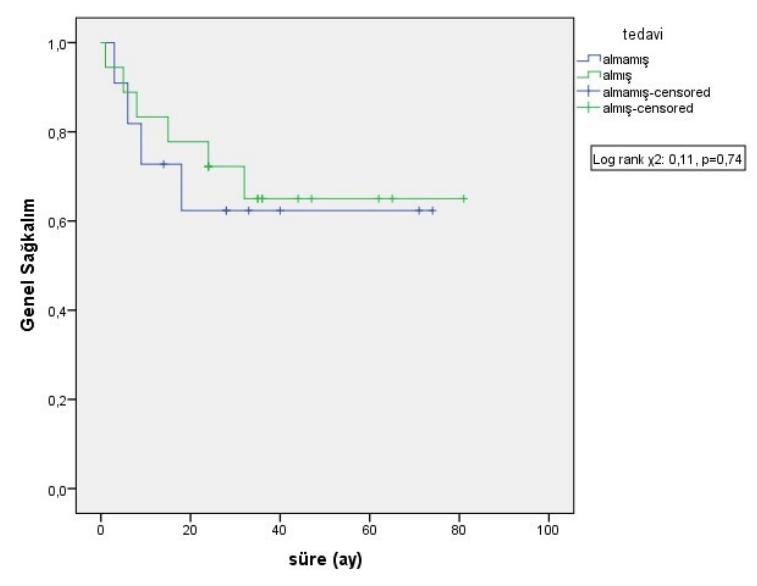

Şekil 4.

Yetmiş beş - yetmiş dokuz yaş hastalarda tedavi alanlarla almayanların sağ kalım karşılaştırması

\section{Tartışma ve Sonuç}

Geriatrik nüfusun kemik iliği profili ile ilgili yayınlar oldukça azdır. İleri yaşlılık olarak tanımlanan $\geq 75$ yaş hasta grubunda yapılan kemik iliği incelemelerinin sonuçlarının değerlendirildiği bu çalışmada en sık endikasyonun sitopeni olduğu, en sik MDS tanısının konulduğu, aspirasyon ile biyopsinin özellikle malign hastalıklarda yüksek oranda uyumlu oldukları ve patolojik tanı konulduktan sonra tedavi verilen hastaların sağ kalımlarının uzadığg bulunmuştur.

Yaşlanma ile kemik iliğinde önemli değişimler görülür. Kemik iliği selülaritesinde ve adaptif immünitede azalma $^{7-9}$ meydana gelirken, myeloproliferatif hasta$\operatorname{lıklar}^{10}$ ve anemi ${ }^{11,12}$ gelişme riskinde artış görülür. Bu değişimler içinde en belirgin olanı selülaritenin azalmasıdır ${ }^{13}$. Otuzlu yaşlarda kemik iliğinin yaklaş1k \%50’sini oluşturan hematopoietik doku, 70'li yaşlarda \%30'a düşer ${ }^{13,14}$. Bu durum trabeküler kemikte azalma ile birlikte hematopoiezde azalmaya neden olur ${ }^{15}$. Böylece anemi gelişebilirken, periferik kanda lökosit sayısı azalmamakla birlikte lenfosit sayısı azalabilir ${ }^{16}$. Geriatrik yaş grubundaki hastalarda anemilerin yaklaşık üçte birinde belirgin bir neden bulunamamaktadır ${ }^{2}$. Bu bilgiler 1şığında sitopenilerin her hangi bir hastalık zemininde olmadan, sadece yaşa bağlı değişikliklere sekonder gelişebileceği akılda tutulmalı, fakat gerçek aneminin yaşa bağlı değişikliklerden ayırt edilmesinin zor olacağı unutulmamalıdır. Nitekim çalışmamızda da anemisi olan hastaların \%12,7'sinde kemik iliğinde anormallik tespit edilmemiştir. Bununla birlikte sitopeniler çalışmamızda incelenen ileri yaşlı grubu hastalarda en sık kemik iliği incelenmesi endikasyonunu oluşturuyordu. Anemi \%87,6 oranında görülürken, lökopeni \%25,9 ve trombositopeni de \%50,6 oranında görülmekte idi. Çalışmamızdaki diğer sık endikasyon plazma hücre diskrazileri şüphesi, daha az sıklıkla lökositoz, trombositoz olup genel popülasyonda da daha nadir görülen endikasyonlardandı. Çocukları ve genç erişkinleri kapsayan genel hasta popülasyonunda en sik kemik iliği değerlendirme endikasyonu akut löseminin tanı ve yönetimi ile lenfomanın evrelendirilmesidir ${ }^{3,4}$. Fakat yaşı hastalarda görülen hastalıkların prevalanslarının farklı olması dolayısı ile bu endikasyonlar farklılık gösterecektir ${ }^{17}$. Çalışmamızda olduğu gibi yaşlı hasta grubunda yapılan diğer çalışmalarda da sitopenilerin en s1k endikasyonu oluşturduğu rapor edilmiştir $^{17-20}$. Yine açıklanamayan lökositoz ve trombositoz ile daha önce tanı almış lenfoma ve MDS'nin takibi diğer endikasyonları oluşturmaktadır. İncelenen hasta grubunda görülmemiş olsa da yine kemik iliğine metastaz yapan ve primeri bilinmeyen malignansilerde de kemik iliği değerlendirme endikasyonu mevcuttur. Daha önce kemik iliğine metastaz yapan nonhematolojik kanserleri incelediğimiz çalışmamızda 75 yaş üstü 2 hastada kemik iliği biyopsi sonucunda meme ve nöroendokrin kökenli malignansi tanısı konulmuştu $^{21}$. Bu hastalar aspirasyon sonuçlarının olmaması dolayısı ile bu çalışmada değerlendirilmemişlerdir.

Yapılan inceleme sonucunda en sık konulan tanı MDS idi. Yine MM, miyeloproliferatif hastalıklar ve NHL MDS'yi takip ediyordu. Bizim çalışmamızda 75 yaş üstü hastalarımızın \%46,9'u kemik iliği biyopsi yapılarak yeni MDS ve MPN tanısı almışlardı. Yine MDS tanısı olmadan akut lösemiden şüphelenilerek yapt1ğımız biyopsiler \%4,9'du. Tüm bu hastalıklar ileri yaş grubunda daha sık görülmektedir. Ortanca görülme yaşı MDS'de 70 iken $^{22}$, MM'de 66-70 yaş arası ${ }^{23}$, MPH'lerde 60 yaş üstü ${ }^{24}$ ve NHL'de 60-70 yaş arasındadır $^{25}$. Görülme sıklıkları yaşla artan tüm bu hastalıklar kemik iliği incelemesi sonucunda ileri yaşıı hasta grubunda daha sık olarak tespit edilmektedir. Diğer konulan tanılara bakıldığında (5 KLL/SLL, 4 AML, 3 miyelofibroz, 2 aplastik anemi, 1 kronik hastalık anemisi, 1 MGUS) tüm tanı konulan hastalıkların ileri yaşta görülme sıklığı artan hastalıklar olduğu görülmektedir. Bu nedenle ileri yaşta kemik iliği incelemesi yapıldığında bu hastalıklar ile karşılaşılma ihtimalinin arttığı göz önünde bulundurulmalıdır.

Diğer önemli bir konu da tanı koyma yöntemlerinin ileri yaşlı hasta grubundaki performansıdır. Genel olarak anamnez ve muayene sonrası düşünülen olası tanıları ortaya koymak için istenen laboratuvar çalışmalarının referans değerleri yaşlı popülasyon için net olarak ortaya konulmalıdır ${ }^{26}$. Özellikle anemi tanısında bu yaş grubu için yeni referans değerleri belirlenebilir. Bugün için erişkinler için DSÖ’nün kullandığ1 erkeklerde $<13 \mathrm{~g} / \mathrm{dl}$, kadınlarda ise $<12 \mathrm{~g} / \mathrm{dl}$ olan hemoglobin değerleri anemi olarak kabul edilmektedir ${ }^{27}$. Oysa yaşlı kadınlarda yapılan bir çalışmada hemoglobin değeri 13-15 g/dl olan kadınların 12-12,9 g/dl olanlara göre daha iyi fiziksel performansa sahip olduklarını gösterilmiştir ${ }^{28}$. Son yapılan geniş çaplı 
çalışmalarda sırasıyla 60 yaş üstü beyaz ırktan erkeklerde ve kadinlarda 13,2 g/dl ve 12,2 g/dl, siyah irktan erkek ve kadınlarda $12,7 \mathrm{~g} / \mathrm{dl}$ ve $11,5 \mathrm{~g} / \mathrm{dl}$ sinırının alınması önerilmiştir ${ }^{29}$. Yaşlılarda anemi önemli morbidite nedenlerindendir. Ilımlı bir kansızlık bile yaşam kalitelerini bozabilir. Çoğu zaman neden beslenme bozukluğu olup diğer nedenler kronik inflamasyon (diabetes mellitüs, kollajen doku hastalıkları gibi), kronik karaciğer ve böbrek hastalığı, konjestif kalp yetmezliği, inme ve MDS olup ve yine pek çoğunda neden açıklanamamıştır ${ }^{5-7,30-32}$. Bizim çalışmamızda folik asit düzeyi 70 hastanın 6'sında $3 \mathrm{ng} / \mathrm{ml}$ ve altında, vitamin B12 düzeyi 70 hastanın 5'inde 211 pg/ml altında ve serum demir düzeyi bakılan 57 hastanın 28 'inde $60 \mathrm{mcg} / \mathrm{dl}$ altında tespit edilmiştir. Demir eksikliği saptanan tüm hastalarımıza endoskopik görüntüleme uygulanmış olup daha çok nütrisyonel alım eksiklikleri olarak değerlendirilmiştir.

Hematolojik incelemenin önemli bir parçası olan periferik kan yayma incelemesi basit ve ucuz bir yöntemdir. Çalışmamızda ilk değerlendirmede kullanılan bu yöntemin bu yaş grubu hastaların tanısı için de önemli bilgiler sağladığı görüldü. Örneğin kemik iliği biyopsisi ile tanı konulan nadir hastalıklar arasında olan KLL incelenen hasta grubunda \%6,2 iken ( 5 hasta), eş zamanlı bak1lan periferik yaymada bu vakaların \%60'1 (3/5) tespit edilmişti. Bu nedenle ilk değerlendirmenin temel bir parçası olmalıdır. Kemik iliği değerlendirmesinin iki temel unsuru olan aspirasyon ve biyopsi sonuçları değerlendirildiğinde, altın standart olarak biyopsi sonucu kabul edildiği zaman her iki yöntemin yüksek oranda uyum içinde olduğu tespit edildi. Aspirasyon sitolojik bilgiler, daha iyi morfoloji ve farklılık gösteren hücre sayıları konusunda bilgi sağlarken, biyopsi ile selülarite ve kemik iliğinin yapısı daha iyi değerlendirilir. Ayrıca biyopsi ile aspirasyonda gelen dry tap sonuçları netleştirilirken, fokal lezyonların da saptanması mümkün olur ${ }^{33}$. İncelenen hasta grubunda yeterli materyalin alınamamış olmasından dolayı nondiagnostik olarak raporlanan 3 hastanın aspirasyon sonuçları elde edilebilmiştir. $\mathrm{Bu}$ nedenle bu iki yöntem birbirlerinin tamamlayıcısı niteliğindedir ve bu yaş grubunda da birlikte yapılmalıdır.

Orta/ileri yaş grubundaki hastalarda ko-morbiditeler, fiziksel durum, sosyal destek, mevcut hastalığın risk kategorisi gibi sağ kalım üzerine etkili birçok faktör mevcuttur. $\mathrm{Bu}$ durum göz ardı edilmemek kaydıyla çalışmanın ana bulgularından bir diğeri de tüm tanı alan hastalar incelendiğinde, hastalığa özgü tedavi almanın istatistiksel olarak anlamlı olmasa da bir sağ kalım avantajına sahip olduğunun görülmesidir. Genel olarak tedavi alan grupta ortanca sağ kalım süresi 69 ay iken, almayan grupta bu süre 35 ay idi. Yine 2 yıllık genel sağ kalım tedavi alan grupta \%57 iken, almayan grupta \%41,7 idi. Yaş gruplarına ayrıldığında tüm yaş gruplarında da tedavi alan hastalarda tahmini kümülatif sağ kalımın daha uzun ve hayatta kalma oranının daha yüksek olduğu görüldü. Bu durum ileri yaşlı hasta grubunda da hastalığa tanı koymanın ve tanıya uygun tedavi uygulamanın gerekli olduğunu göstermektedir. $\mathrm{Bu}$ nedenle 75 yaş ve üstü orta/ileri yaşlı hastalara da kemik iliği incelenmesi yapılmasından sakınılmamalıdır. Her ne kadar ileri yaş grubuna özgü komplikasyon oranları çalışılmamış olsa da genel popülasyonda ciddi komplikasyon görülme ora$\mathrm{n} 1 \% 0,05$ olarak rapor edilmiştir. Kanama en s1k komplikasyon olarak bildirilmiş, MPH varlığı, aspirin kullanımı, warfarin tedavisi, disemine intravasküler koagulasyon ve obezite risk faktörleri olarak rapor edilmiştir $^{34}$. İleri yaşta daha sık görülen bu risk faktörlerin varlığında kemik iliği incelemesi yapılacak ise daha dikkatli olunması uygun olacaktır. Bu çalışmada hastalarda her hangi bir komplikasyon gelişmemiştir.

Sonuç olarak orta/ileri yaşlılık olarak tanımlanan 75 yaş ve üstü hastalarda, ileri yaşa özgü hematolojik ve bazı non-hematolojik hastalıkların tanısının konulması için aspirasyon ve biyopsiden oluşan kemik iliği incelemesi güvenle yapılabilir. Kemik iliği incelemesinin endikasyonları çocuk ve genç erişkinlerinkinden farklidır. $\mathrm{Bu}$ inceleme ile tanısı konulan hastalıklarda uygulanan tedaviler ile sağ kalım artmaktadır. Bu nedenle endikasyon varlığında, tanının konulması ve uygun tedavinin başlanması yolu ile sağ kalımı arttırmak için kemik iliği incelemesi bu yaş grubuna önerilmelidir.

Etik Kurul Onay Bilgisi:

Onaylayan Kurul: Başkent Üniversitesi Tıp ve Sağlık Bilimleri Araştırma Kurulu.

Onay Tarihi: 18.02 .2020

Karar No: KA20/48

\section{Kaynaklar}

1. Türkiye istatistik kurumu, Temel istatistikler, http://www.tuik.gov.tr/UstMenu.do?metod=temelist, en son erişim 07/05/2020

2. Prabhakar M, Ershler WB, Longo DL. Bone marrow, thymus and blood: changes across the lifespan. Aging health. 2009;5:385-93

3. Al-Gwaiz LA. Analysis of 3494 bone marrow examinations in a referral hospital: indications and interpretations. Saudi Med J.1997;18:144-7

4. Bashawri LA. Bone marrow examination: indications and diagnostic value. Saudi Med J. 2002;23:191-6

5. World Health Organization. (2017). World report on Ageing and Health. http:// apps.who.int/iris/bitstream/10665/ 186463/ 1/9789240694811_eng.pdf (Erişim tarihi: 07.05.2018)

6. Kaur G, Basu S, Kaur P, Sood T. Metastatic bone marrow tumors: Study of nine cases and review of the literature. J Blood Disord Transfus 2011;2:110

7. Longo, DL. Immunology of aging. In: Paul, WE., editor. Fundamental Immunology. Vol. 5th edition. Williams and Wilkins; Philadelphia, Lippicott: 2003. p. 1043-1075.

8. Hakim FT, Gress RE. Immunosenescence: deficits in adaptive immunity in the elderly. Tissue Antigens 2007;70:179-89. 


\section{Yaşlılarda Kemik İliği Değerlendirmesi}

9. Linton PJ, Dorshkind K. Age-related changes in lymphocyte development and function. Nat Immunol 2004;5:133-9.

10. Lichtman MA, Rowe JM. The relationship of patient age to the pathobiology of the clonal myeloid diseases. Semin Oncol 2004;31:185-97.

11. Beghe C, Wilson A, Ershler WB. Prevalence and outcomes of anemia in geriatrics: a systematic review of the literature. Am J Med 2004;116(Suppl 7A):3S-10S

12. Guralnik JM, Eisenstaedt RS, Ferrucci L, Klein HG, Woodman RC. Prevalence of anemia in persons 65 years and older in the United States: evidence for a high rate of unexplained anemia. Blood 2004;104:2263-8.

13. Hartsock RJ, Smith EB, Petty CS. Normal variations with aging of the amount of hematopoietic tissue in bone marrow from the anterior iliac crest. a study made from 177 cases of sudden death examined by necropsy. Am J Clin Pathol 1965;43:326-31.

14. Ricci C, Cova M, Kang YS, et al. Normal age-related patterns of cellular and fatty bone marrow distribution in the axial skeleton: MR imaging study. Radiology 1990;177:83-8

15. Justesen J, Stenderup K, Ebbesen EN, Mosekilde L, Steiniche T, Kassem M. Adipocyte tissue volume in bone marrow is increased with aging and in patients with osteoporosis. Biogerontology 2001;2:165-71

16. MacKinney AA Jr. Effect of aging on the peripheral blood lymphocyte count. J Gerontol 1978;33: 213-6

17. Manion EM, Rosenthal NS. Bone marrow biopsies in patients 85 years or older. Am J Clin Pathol. 2008;130:832-5.

18. Sulakshana MS, Ahmed SM, Raghupati AR. Bone marrow changes in elderly. IAIM, 2015;2:27-33

19. Gulati A, Mandal T, Kaushal V, Kaushik R, Thakur S. Bone marrow disease profile in geriatric patients: an institutiona experience. Indian J Hematol Blood Transfus. 2018;34:540-3

20. Öztorun HS, Turgut T, Sürmeli DM, ve ark. Geriatri kliniğimizde yapılan kemik iliği biyopsi sonuçlarının çok yönlü değerlendirilmesi: tanı, prezentasyon ve mortalite. J Contemp Med, 2018;8:122-7

21. Aytan P, Kocer NE, Yeral M, et al. Non-hematologic malignancies metastasing to the bone marrow: a record-based descriptive study from a tertiary center. UHOD, 2020;30:238-45

22. French registry of acute leukemia and myelodysplastic syndromes. Age distribution and hemogram analysis of the 4496 cases recorded during 1982-1983 and classified according to FAB criteria. Groupe Francais de Morphologie Hematologique. Cancer. 1987;60:1385-94.

23. Türk Hematoloji Derneği, Multipl Myelom ulusal tanı ve tedavi kılavuzu, ISBN: 978-605-80353-4-8, Edition 1.03 - Mart 2020:1, Galenos Yayınevi, Istanbul, Türkiye

24. Thapa B, Rogers HJ. Cancer, Myeloproliferative Neoplasms. [Updated 2019 Nov 13]. In: StatPearls [Internet]. Treasure Island (FL): StatPearls Publishing; 2020 Jan-. Available from: https://www.ncbi.nlm.nih.gov/books/NBK531464/

25. Roman E, Smith AG. Epidemiology of lymphomas. Histopathol 2011;58:4-14.

26. Vásárhelyi B, Debreczeni LA. Lab test findings in the elderly. EJIFCC. 2017;28:328-32

27. Blanc B, Finch CA, Hallberg L. Nutritional anaemias. Report of a WHO Scientific Group. WHO Tech Rep Ser 1968;405:140

28. Chaves PH, Xue QL, Guralnik JM, Ferrucci L, Volpato S, Fried LP. What constitutes normal hemoglobin concentration in community-dwelling disabled older women? J Am Geriatr Soc 2004;52:1811-6

29. Beutler E, Waalen J. The definition of anemia: what is the lower limit of normal of the blood hemoglobin concentration? Blood. 2006;107:1747

30. Steensma DP, Tefferi A. Anemia in the elderly: how should we define it, when does it matter, and what can be done? Mayo Clin Proc. 2007;82:958-66.

31. Eisenstaedt R, Penninx BW, Woodman RC. Anemia in the elderly: current understanding and emerging concepts. Blood Rev. 2006;20:213-6

32. Balducci L. Epidemiology of anemia in the elderly: information on diagnostic evaluation. J Am Geriatr Soc. 2003;51(3suppl):S2-S9

33. Block M. Bone marrow examination: aspiration or core biopsy, smear or sections, hematoxylin-eosin or Romanowsky stainwhich combination? Arch Pathol Lab Med 1976;100:454-6

34. Bain BJ. Bone marrow biopsy morbidity and mortality. $\mathrm{Br} \mathrm{J}$ Haematol. 2003;121:949-51. 
